\title{
Monitored Exercise and Supplemental Oxygen Improve Exercise Tolerance, Heart Rate Response and Symptoms in Three Females with Post-COVID Syndrome: A Case Series
}

\section{Noah Greenspan}

Pulmonary Wellness Foundation https://orcid.org/0000-0002-0931-0174

\section{Marion Mackles}

Pulmonary Wellness Foundation

\section{Greg Hullstrung}

H\&D Physical Therapy

\section{Wai Chin}

Pulmonary Wellness Foundation

\section{Robert Kaner}

Weill Cornell Medical Center

\section{Louis DePalo}

Mount Sinai Health Center at Hudson Yards

Julie Walsh-Messinger ( $\nabla$ jmessinger1@udayton.edu )

University of Dayton

\section{Case Report}

Keywords: Post-Acute Sequelae of SARS-CoV-2 Infection, SARS-CoV-2, COVID-19, post-COVID syndrome, long COVID, long-hauler syndrome, post-viral syndrome, cardiopulmonary rehabilitation

Posted Date: June 1st, 2021

DOI: https://doi.org/10.21203/rs.3.rs-463053/v2

License: (c) (i) This work is licensed under a Creative Commons Attribution 4.0 International License. Read Full License 


\section{Abstract}

Background: It is now recognized that a significant proportion of previously healthy young and middleaged adults who contract COVID-19 will develop protracted post-viral symptoms including fatigue, dyspnea, cough, post-exertional malaise and autonomic dysfunction. Effective treatment approaches for this post-COVID syndrome (PCS) are crucially needed.

Methods: Three previously healthy females (ages 34, 39, and 38) who contracted COVID-19 in Spring 2020 and subsequently developed PCS received monitored aerobic exercise combined with supplemental oxygen beginning seven or eight months following acute-illness. Pre- and post-treatment exercise tolerance was tested using the Bensen treadmill protocol. Treatment consisted of 22 sessions of graduated treadmill exercise during which 6 liters of continuous oxygen was delivered via nasal canula.

Findings: All patients demonstrated $~ 54 \%$ improvement in exercise tolerance, improvement in heart rate and systolic blood pressure response during exercise, and remission or improvement of symptoms, including cough, dyspnea on exertion, laryngeal inflammation, chest discomfort, fatigue, and/or postexertional malaise.

Interpretation: We show that measured, monitored exercise combined with supplemental oxygen improved lingering symptoms in three female PCS patients. Supplemental oxygen may reduce postexercise inflammation, therefore providing the benefits of exercise while reducing the likelihood of PCS symptom exacerbation. Due to the variable nature of PCS, it is crucial to individualize treatment protocols and to continually evaluate and modify each protocol based upon individual patient response.

Funding: This work was funded by the Pulmonary Wellness Foundation.

\section{Introduction}

The highly contagious novel SARS-CoV-2 virus, first identified in Wuhan, China in late 2019, has infected over 151 million people as of May $2,2021 .{ }^{1}$ Despite early reports that COVID-19, the disease caused by SARS-CoV-2, was predominantly a respiratory illness, it is now clear that the virus can affect multiple physiological systems, including the respiratory, cardiovascular, neurologic and/or gastrointestinal systems. ${ }^{2}$ Early reports also suggested that previously healthy young and middle-aged adults would recover fully from the virus within two to three weeks; however, it is now recognized that a substantial percentage, more frequently females, ${ }^{3-7}$ do not fully recover within one month, ${ }^{3,7,8}$ and up to 45 percent may experience persistent symptoms for two or more months following onset of acute illness. ${ }^{3,4,6}$ The prognosis for those who develop post-COVID syndrome (PCS), also referred to as "long COVID" or "Ionghauler syndrome," is unknown, but anecdotal reports suggest that symptoms can persist for a year or more. ${ }^{9,10}$

There is consensus that PCS is marked by a heterogenous constellation of multisystemic symptoms and post-viral complications, with fatigue, cough, dyspnea, exercise intolerance, headache, brain fog, and 
smell loss/alterations reported most frequently . Some PCS patients present with exercise intolerance 7,11 and/or autonomic dysfunction ${ }^{7,11-13}$ which create a particular rehabilitation challenge as traditional cardiopulmonary protocols are often too vigorous for this population and could exacerbate PCS symptoms.

Despite known performance enhancing effects, the use of supplemental oxygen is not standard practice during cardiopulmonary rehabilitation with non-hypoxemic patients. Some, but not all, ${ }^{14}$ clinical trials of supplemental oxygen during exercise therapy for chronic obstructive pulmonary disease (COPD), pulmonary fibrosis (PF) and other interstitial lung disease (ILD) suggest that it increases peak work rate and exercise tolerance, reduces perceived dyspnea and other symptoms, and improves ability to engage in activities of daily living. ${ }^{15-19}$ Supplemental oxygen also appears to mitigate post-exercise inflammation, ${ }^{20,21}$ which may be the mechanism underlying PCS associated exercise intolerance. Herein, we present our experience of using progressive treadmill exercise and supplemental oxygen in three nonhospitalized female PCS patients.

\section{Methods}

\subsection{Case Histories}

Demographics and more detailed medical histories are presented in Table 1.

\subsubsection{Patient $A$}

Patient A is 38-year-old Caucasian female with a past medical history of infrequent childhood seizures beginning at age eight, which co-occurred with vasovagal syncope between ages $25-30$, and Lyme disease, which was diagnosed and treated with IV ozone therapy and supplements in 2018, two years after initial symptom onset.

She contracted COVID-19 and tested positive by PCR in the second week of March 2020 and subsequently showed the presence of antibodies. Patient A initially experienced cold-like symptoms, including fever (103 F), dyspnea both at rest and upon exertion, rhinitis, and pharyngitis, followed by an initially productive, then dry, cough, nausea, diarrhea, and visual and auditory hallucinations that lasted for approximately three weeks.

Over the next several months she experienced periods of symptom remission for several weeks, followed by recurrence of dyspnea, chest tightness, anxiety, and panic attacks, and . She also experienced postexertional malaise, increased dyspnea, and chest pressure within 24-48 hours of taking an hour-long walk or yoga class. She reported mild symptom relief with albuterol sulfate but tried to limit its use due to increased jitteriness. Medications at the time of her initial evaluation included daily hydroxychloroquine, prednisone, Topamax, and Adderall as needed, as well as multiple non-prescription anti-inflammatory supplements. 


\subsubsection{Patient $B$}

Patient B is a 38-year-old Caucasian female with a medical history of allergic rhinitis, allergic reaction to penicillin, amoxicillin, and tetracycline, degenerative disc disease, and three hospitalizations in 2002 for medical complications associated with anorexia nervosa, which has been in partial-to-full remission since 2004. Her psychiatric history also includes premorbid diagnoses of persistent depressive disorder, generalized anxiety disorder and attention-deficit hyperactivity disorder. She was a nationally competitive swimmer and exercised regularly prior to her illness.

Patient B contracted COVID-19 mid-March 2020, and initially experienced rhinitis, dry cough, and chest tightness. Those symptoms resolved completely three days later which coincided with sudden onset anosmia, ageusia, and dysgeusia. The following week she developed fever (102 F) with intermittent borderline hypothermia (95 F), return of cough, dyspnea on exertion and at rest, chills, and myalgias, at which time she was clinician-diagnosed with COVID-19 as PCR testing was unavailable. She also experienced olfactory hallucinations on three occasions and had multiple dermatologic issues including transient "white" hives and "canker-like" sores that would last two to three hours at a time.

The second week of April, Patient B was admitted to the ER at which time chest x-ray revealed "possible mild pleural effusions." She remained ineligible for PCR testing but was again clinician-diagnosed with COVID-19 and discharged without further testing or treatment. Her dyspnea, cough, and fatigue worsened over the next month and she began experiencing oxygen desaturation (low 80's and high 70's) after speaking for more than 10-15 minutes or climbing a flight of stairs, which coincided with heart rate lability (40 to $154 \mathrm{bpm}$ within 60 seconds). Other symptoms included brain fog, impaired memory, nightmares, and night sweats. Patient $B$ had two more ER admissions in June for oxygen desaturation, chest pain and dyspnea on exertion, at which time she was diagnosed with hypertension. Her last ER admission, in late July, was for chest pain which, was attributed to a cough-induced muscle strain. Pulmonary function tests, echocardiogram, and cardiac stress test were all normal. Holter monitor showed inappropriate sinus tachycardia. She continued to experience daily fevers (99.5-102) until early October.

Medications at the time of her initial evaluation included Zoloft, Adderall XR, and TriNessa Lo daily, as well as Singulair (for allergic rhinitis), trazadone, and albuterol as needed. After her evaluation she was diagnosed with coronary vasospasms for which daily Procardia XL was prescribed.

\subsubsection{Patient C}

Patient $C$ is 34-year-old Black female who has a medical history significant for sickle-cell trait (carrier only), HSV-1, and a childhood history of Tourette's syndrome (in remission). She was a regular runner prior to her illness.

Patient $\mathrm{C}$ began experiencing dyspnea on exertion in mid-April 2020. She was clinician diagnosed with COVID-19 in the emergency department the following day and subsequently released without treatment. 
She continued to experience dyspnea without oxygen desaturation for months and suspected pneumonia but continued to run 1-2 miles several times a week. An August chest CT was "mostly normal," but per medical records showed some post-viral inflammation and "damage to approximately $30 \%$ of smaller blood vessels in the lungs."

In early August, Patient $C$ experienced severe laryngeal spasms for seven days, after using albuterol and Advair. She discontinued those medications but continued to experience persistent inflammation in her throat and larynx. A January CT scan was normal with the exception of mildly dilated distal esophagus. After endoscopic evaluation was normal, her ENT suggested her symptoms might indicate irritable larynx syndrome and/or possible nerve damage.

Medications at the time of Patient C's initial evaluation included Albuterol, Advair Naproxen, Celebrex, and non-prescription supplements.

\subsection{Exercise Tolerance Testing}

Exercise tolerance was tested pre- and post-treatment using the Bensen ${ }^{22}$ treadmill protocol (see Supplemental Table 1). The Bensen protocol was selected because MET increase at each stage is more gradual and consistent than other more frequently utilized maximal and sub-maximal protocols and is therefore less likely to induce post-exertional malaise or exacerbate PCS symptoms. The protocol begins at a speed of $1.0 \mathrm{MPH}$ with a $0 \%$ incline (1.77 METs) for two minutes, after which intensity is increased by approximately $25 \%$ every two minutes, alternating between increases in speed and incline until ageadjusted (200 - age) heart rate or blood pressure maximum is reached, moderate (somewhat hard to hard) symptom burden is reported, or the patient requests to stop.

The exercise tolerance tests were performed on room air. Heart rate and rhythm were monitored continuously via ECG. Blood pressure and oxygen saturation were measured at rest, during each exercise stage, and five-minutes post exercise. Rate of Perceived Exertion (RPE) and Breathlessness were obtained at peak exercise using the Borg scales. ${ }^{23}$

\subsection{Treatment Protocol}

After initial testing, patients underwent two (A \& C) or three (B) exercise sessions per week for a total of 22 treatment sessions. The initial sessions were approximately $25 \%$ longer in duration and lower in intensity than the exercise tolerance test, such that $80-100 \%$ of peak exercise intensity was achieved within three to six sessions. In subsequent sessions, time and intensity were increased by no more than 0.5 METS, as tolerated based upon vital signs and patient-reported symptoms following the previous session and during exercise.

The patients received 6 liters per minute of continuous oxygen via nasal cannula regardless of oxygen saturation 5 minutes prior to, during, and 5 minutes post-exercise. Heart rate and rhythm were monitored 
continuously via ECG, and blood pressure and oxygen saturation were measured at rest, every 3-5 minutes during exercise, and five-minutes post exercise.

\section{Outcomes}

\section{Physiological Measures}

Heart rate and blood pressure readings at each pre- and post-treatment exercise stage are displayed in Figures 1 and 2. For each session, peak MET level, heart rate and blood pressure at rest, peak exercise, and 5-minutes post recovery can be found in the supplementary materials (Supplemental Figures, 1, 2, 3, and 4).

Post-treatment, patients A and B were able to tolerate 18 minutes of treadmill exercise at a peak intensity of $3.7 \mathrm{mph}$ with a $13 \%$ incline. This translates into a workload of 10.47 METs compared to $6.82 \mathrm{METs}$ at initial testing and represents an improvement of $53.5 \%$. Patient $C$ was able to tolerate 20 minutes of treadmill exercise at a peak intensity of $4.7 \mathrm{mph}$ with a $13 \%$ incline, which translates into a workload of 13.0 METs as compared to 8.43 METs upon initial testing and indicates $54.2 \%$ improvement.

All three patients demonstrated improvement in heart rate and comparable or improved systolic blood pressure during each test stage. We also averaged heart rate and blood pressure at rest and five-minutes post-recovery across the first eleven and second eleven treatment sessions (see Table 2). Patient A's average heart rate decreased 4.22 points at rest and 5.51 points 5 -minutes post-exercise. Patient B's resting heart rate decreased 9 points, and systolic blood pressure at rest and 5-minutes post-exercise decreased 4.72 and 7.64 points, respectively. Notably, the standard deviation for her resting systolic blood pressure also decreased by 7.32 points, suggesting less variability from session to session. Patient C's resting heart rate decreased by 3.46 points; however, her heart rate 5 -minutes post exercise and systolic blood pressure at rest increased by 4.37 and 6.54 points, respectively.

\section{PCS Symptoms}

Post-treatment, Patient A's dyspnea, chest tightness, fatigue, and post-exertional malaise had significantly improved. Patient B reported significant improvement in cough and cognitive function, with near remission of dyspnea, night sweats, and nightmares. She continued to experience occasional mild fevers for six additional weeks but has now been fever-free for two months. Patient $\mathrm{C}$ reported nearremission of dyspnea and more gradual but continuing improvement in throat and larynx inflammation.

\section{Discussion}

All three patients reported in this case series were young, generally healthy, and active prior to contracting COVID-19 in March or April 2010. Although acute and post-acute illness presentations were variable across the patients, all three demonstrated improvement in exercise tolerance, physiological response to 
exercise, and PCS symptoms after 22 treatment sessions of monitored treadmill exercise combined with supplemental oxygen.

Current recommendations regarding the use of exercise in PCS rehabilitation range from initiating exercise therapy only after the patient has been symptom free for at least two weeks ${ }^{24}$ to beginning a structured aerobic and resistance training program. ${ }^{25}$ Hyperinflammation, potentially mediated by mast cell activation, has also been proposed as one potential mechanism underlying PCS. ${ }^{26} \mathrm{~A}$ substantially less vigorous exercise protocol including breathwork, relaxation training and meditation is recommended for patients who are currently in a hyperinflammatory state, as we have found that even minimal physical exertion (e.g. walking up a flight of stairs), emotional stress, and/or cognitive load can exacerbate symptoms. However, once hyperinflammation subsides, our treatment outcomes suggest that very gradual, carefully monitored exercise combined with supplemental oxygen may improve lingering symptoms and autonomic function for some PCS patients.

Typically, inflammatory (TNFa, IL-1 $1 \beta, \mathrm{IL}-6$ ) and anti-inflammatory cytokines (IL-10) as well as cytokine inhibitors (IL-1ra, sTNF-r1, sTNF-r2) are released following exercise. ${ }^{27}$ One possible explanation for PCS related exercise intolerance is that these patients are not releasing enough anti-inflammatory cytokines and/or cytokine inhibitors post-exercise, leading to symptom exacerbation and post-exertional malaise. Oxygen, which reduces post-exercise inflammation, ${ }^{20,21}$ may equalize inflammatory and antiinflammatory cytokines, allowing the body to normally respond to exercise in those with PCS.

It must be noted that PCS symptomatology and course are highly variable, both between patients and within individuals. As such, patient safety should be maximized by requiring a comprehensive cardiac, respiratory, and neurologic evaluation and clearance, and conducting a thorough pre-rehabilitation assessment to rule out potential complications that contraindicate activity and exercise. In addition, clinical course and pre-, intra- and post-treatment heart rate and rhythm via ECG, blood pressure, and oxygen saturation should be closely monitored, and exercise time and intensity should be increased very conservatively. The potential for post-exertional malaise (PEM) or exacerbation of symptoms should also be regularly assessed. One rehabilitation protocol will not work for every patient and any treatment plan needs to be monitored closely and adjusted for each individual as needed.

It has been proposed that COVID-19 might be associated with myalgic encephalomyelitis/chronic fatigue syndrome (ME/CFS), ${ }^{28}$ for which the appropriateness of graded exercise therapy is controversial. ${ }^{29,30}$ However, findings from a recent study that compared the autonomic functions of PCS patients with and without fatigue showed that autonomic dysfunction in both groups differed from that previously observed in ME/CFS, ${ }^{31}$ suggesting that while they share similar features they may not be the same syndrome. Furthermore, combining supplemental oxygen with treadmill exercise reduces stress of the physical activity on the body, and our early success with its use provides support for conducting larger clinical trials to test the efficacy of graded treadmill exercise with supplemental oxygen for treatment of PCS as well as ME/CFS and other syndromes with overlapping symptoms. 


\section{SUMMARY}

In conclusion, graduated treadmill exercise combined with supplemental oxygen may improve exercise tolerance and symptoms in PCS patients. Still, a one-size-fits-all approach will help all PCS patients and may be harmful to some. Individualized, flexible treatment plans are recommended, as is further research of the treatment described here as well as individual differences in treatment response.

\section{References}

1. Coronavirus disease (COVID-19) pandemic. 2020. (Accessed 09/07/2020, at https://www.who.int/emergencies/diseases/novel-coronavirus-2019.)

2. Dennis A, Wamil M, Kapur S, et al. Multi-organ impairment in low-risk individuals with long COVID. medRxiv 2020:2020.10.14.20212555.

3. Bliddal S, Banasik K, Pedersen OB, et al. Acute and persistent symptoms in non-hospitalized PCRconfirmed COVID-19 patients. medRxiv 2021:2021.01.22.21249945.

4. Logue JK, Franko NM, McCulloch DJ, et al. Sequelae in Adults at 6 Months After COVID-19 Infection. JAMA Network Open 2021;4:e210830-e.

5. Mahmud R, Rahman MM, Rassel MA, et al. Post-COVID-19 syndrome among symptomatic COVID-19 patients: A prospective cohort study in a tertiary care center of Bangladesh. PLOS ONE 2021;16:e0249644.

6. Petersen MS, Kristiansen MF, Hanusson KD, et al. Long COVID in the Faroe Islands - a longitudinal study among non-hospitalized patients. Clinical Infectious Diseases 2020.

7. Walsh-Messinger J, Manis H, Vrabec A, et al. The Kids Are Not Alright: A Preliminary Report of PostCOVID Syndrome in University Students. medRxiv 2020:2020.11.24.20238261.

8. Bell ML, Catalfamo CJ, Farland LV, et al. Post-acute sequelae of COVID-19 in a non-hospitalized cohort: results from the Arizona CoVHORT. medRxiv 2021:2021.03.29.21254588.

9. Holcomb M, Waldrop T. This Covid long-hauler is afraid to take a shower a year after her infection because of the amount of hair she has lost. CNN 2021 March 10, 2021.

10. Wallace AE. I've Been Sick From COVID-19 For Almost A Year. Here's What My Life Has Been Like. Huffington Post 2021 March 3, 2021.

11. Varughese RA, Lam GY, Brotto A, et al. Reduced Exercise Tolerance in Long-COVID Patients. Am J Respir Crit Care Med 2021:A4116.

12. Blitshteyn S, Whitelaw S. Postural orthostatic tachycardia syndrome (POTS) and other autonomic disorders after COVID-19 infection: a case series of 20 patients. Immunologic Research 2021;69:20511.

13. Shouman K, Vanichkachorn G, Cheshire WP, et al. Autonomic dysfunction following COVID-19 infection: an early experience. Clinical Autonomic Research 2021. 
14. Spielmanns M, Fuchs-Bergsma C, Winkler A, Fox G, Krüger S, Baum K. Effects of Oxygen Supply During Training on Subjects With COPD Who Are Normoxemic at Rest and During Exercise: A Blinded Randomized Controlled Trial. Respiratory Care 2015;60:540.

15. Eves ND, Sandmeyer LC, Wong EY, et al. Helium-hyperoxia: a novel intervention to improve the benefits of pulmonary rehabilitation for patients with COPD. Chest 2009;135:609-18.

16. Neunhäuserer D, Steidle-Kloc E, Weiss G, et al. Supplemental Oxygen During High-Intensity Exercise Training in Nonhypoxemic Chronic Obstructive Pulmonary Disease. The American Journal of Medicine 2016;129:1185-93.

17. Dowman LM, McDonald CF, Bozinovski S, et al. Greater endurance capacity and improved dyspnoea with acute oxygen supplementation in idiopathic pulmonary fibrosis patients without resting hypoxaemia. Respirology 2017;22:957-64.

18. Emtner M, Porszasz J, Burns M, Somfay A, Casaburi R. Benefits of supplemental oxygen in exercise training in nonhypoxemic chronic obstructive pulmonary disease patients. Am J Respir Crit Care Med 2003;168:1034-42.

19. Somfay A, Porszasz J, Lee SM, Casaburi R. Dose-response effect of oxygen on hyperinflation and exercise endurance in nonhypoxaemic COPD patients. Eur Respir J 2001;18:77-84.

20. van Helvoort HAC, Heijdra YF, Heunks LMA, et al. Supplemental Oxygen Prevents Exercise-induced Oxidative Stress in Muscle-wasted Patients with Chronic Obstructive Pulmonary Disease. American Journal of Respiratory and Critical Care Medicine 2006;173:1122-9.

21. Andrade DR, Pinto KC, de Castro JS, et al. Oxygen supplementation increases the total work and muscle damage markers but reduces the inflammatory response in COPD patients. Respiratory Physiology \& Neurobiology 2020;280:103475.

22. Mola A, Whiteson JH, Rey MJ. Cardiovascular Disorders. In: Flanagan SR, Zaretsky H, Moroz A, eds. Medical Aspects of Disability. Fourth Edition ed. New York, NY: Springer Publishing Company, LLC; 2010:119-46.

23. Borg G. Borg's Perceived Exertion and Pain Scales. Champaign, IL:: Human Kinetics; 1998.

24. Barker-Davies RM, Sullivan O, Senaratne KPP, et al. The Stanford Hall consensus statement for postCOVID-19 rehabilitation. British Journal of Sports Medicine 2020;54:949.

25. Dani M, Dirksen A, Taraborrelli P, et al. Autonomic dysfunction in 'Iong COVID': rationale, physiology and management strategies. Clin Med (Lond) 2021;21:e63-e7.

26. Oronsky B, Larson C, Hammond TC, et al. A Review of Persistent Post-COVID Syndrome (PPCS). Clinical Reviews in Allergy \& Immunology 2021.

27. Ostrowski K, Rohde T, Asp S, Schjerling P, Pedersen BK. Pro- and anti-inflammatory cytokine balance in strenuous exercise in humans. The Journal of Physiology 1999;515:287-91.

28. Komaroff AL, Bateman L. Will COVID-19 Lead to Myalgic Encephalomyelitis/Chronic Fatigue Syndrome? Frontiers in Medicine 2021;7. 
29. Wilshire CE, Kindlon T, Courtney R, et al. Rethinking the treatment of chronic fatigue syndrome-a reanalysis and evaluation of findings from a recent major trial of graded exercise and CBT. BMC Psychology 2018;6:6.

30. White PD, Goldsmith KA, Johnson AL, et al. Comparison of adaptive pacing therapy, cognitive behaviour therapy, graded exercise therapy, and specialist medical care for chronic fatigue syndrome (PACE): a randomised trial. Lancet 2011;377:823-36.

31. Townsend L, Moloney D, Finucane C, et al. Fatigue following COVID-19 infection is not associated with autonomic dysfunction. PLOS ONE 2021;16:e0247280.

\section{Declarations}

Funding: This work was funded by the Pulmonary Wellness Foundation.

Conflict of Interest Disclosure: Noah Greenspan is the Founder of the Pulmonary Wellness Foundation and Post-COVID Rehabilitation \& Recovery Clinic at H\&D Physical Therapy. Gregory Hullstrung is a Partner at H\&D Physical Therapy.

\section{Tables}

Table 1. Demographics and Health History for Each Case 


\begin{tabular}{|c|c|c|c|}
\hline & Patient A & Patient B & Patient C \\
\hline \multicolumn{4}{|l|}{ Demographics } \\
\hline Age & 34 & 39 & 38 \\
\hline Sex & F & $\mathrm{F}$ & $\mathrm{F}$ \\
\hline Race & White & White & Black \\
\hline \multicolumn{4}{|l|}{$\begin{array}{l}\text { Premorbid } \\
\text { Health }\end{array}$} \\
\hline $\begin{array}{l}\text { Smoking } \\
\text { status }\end{array}$ & Never Smoker & Never Smoker & Never Smoker \\
\hline $\begin{array}{l}\text { Health } \\
\text { history }\end{array}$ & $\begin{array}{l}\text {-Childhood seizures, } \\
\text { dx at age eight } \\
\text {-Lyme Disease, } d x \text { in } \\
2018\end{array}$ & $\begin{array}{l}\text {-Anorexia, dx in } 2002 \\
\text {-Allergic rhinitis } \\
\text {-Allergic reaction to penicillin, } \\
\text { amoxicillin, and tetracycline } \\
\text {-Degenerative disc disease, dx } \\
\text { in } 2015 \\
\text {-Persistent depressive } \\
\text { disorder } \\
\text {-Generalized anxiety disorder } \\
\text {-Attention-deficit hyperactivity } \\
\text { disorder }\end{array}$ & $\begin{array}{l}\text {-Sickle-cell trait (carrier } \\
\text { only) } \\
\text {-HSV-1 } \\
\text {-Tourette's syndrome, dx in } \\
\text { childhood and in remission }\end{array}$ \\
\hline \multicolumn{4}{|l|}{ COVID-19 } \\
\hline PCR test & Positive & $\begin{array}{l}\text { Denied testing due to state } \\
\text { testing restrictions }\end{array}$ & $\begin{array}{l}\text { Denied testing due to state } \\
\text { testing restrictions }\end{array}$ \\
\hline $\begin{array}{l}\text { Antibody } \\
\text { test }\end{array}$ & Positive & $\begin{array}{l}\text { Negative when tested four } \\
\text { months post-acute COVID }\end{array}$ & \\
\hline $\begin{array}{c}\text { Hospital } \\
\text { admissions }\end{array}$ & 0 & 0 & 0 \\
\hline $\begin{array}{c}\text { ED } \\
\text { admissions }\end{array}$ & 0 & 4 & 1 \\
\hline \multicolumn{4}{|l|}{$\begin{array}{l}\text { At time } \\
\text { treatment was } \\
\text { initiated }\end{array}$} \\
\hline $\begin{array}{r}\text { Duration of } \\
\text { PCS symptoms }\end{array}$ & $\sim 218$ days & $\sim 258$ days & $\sim 189$ days \\
\hline Medications & $\begin{array}{l}\text { - } \\
\text { Hydroxychloroquine } \\
\text { QD } \\
\text {-prednisone QD } \\
\text {-Topamax QD } \\
\text {-Adderall PRN } \\
\text {-non-Prescription } \\
\text { supplements }\end{array}$ & $\begin{array}{l}\text {-Procardia ER QD } \\
\text {-Zoloft QD } \\
\text {-Adderall XR QD } \\
\text {-TriNessa Lo QD } \\
\text {-Singulair PRN } \\
\text {-trazadone PRN } \\
\text {-albuterol PRN }\end{array}$ & $\begin{array}{l}\text {-Albuterol QD } \\
\text {-Advair QD } \\
\text {-Naproxen QD } \\
\text {-Celebrex QD } \\
\text {-non-prescription } \\
\text { supplements }\end{array}$ \\
\hline
\end{tabular}

Table 2. Heart Rate and Blood Pressure Readings at Rest and 5-Minutes Post-Exercise Averaged Across Treatment

Page $11 / 15$ 
Sessions 1-11 and 12-22.

\begin{tabular}{|c|c|c|c|c|c|c|c|c|c|}
\hline & \multicolumn{3}{|c|}{ Patient A } & \multicolumn{3}{|c|}{ Patient B } & \multicolumn{3}{|c|}{ Patient C } \\
\hline & $\begin{array}{c}\text { Sessions } \\
1-11\end{array}$ & $\begin{array}{c}\text { Sessions } \\
12-22\end{array}$ & Change & $\begin{array}{c}\text { Sessions } \\
1-11\end{array}$ & $\begin{array}{c}\text { Sessions } \\
12-22\end{array}$ & Change & $\begin{array}{c}\text { Sessions } \\
1-11\end{array}$ & $\begin{array}{c}\text { Sessions } \\
12-22\end{array}$ & Change \\
\hline & $M(S D)$ & $M(S D)$ & $M(S D)$ & $M(S D)$ & $M(S D)$ & $M(S D)$ & $M(S D)$ & $M(S D)$ & $M(S D)$ \\
\hline $\begin{array}{l}\text { Heart } \\
\text { rate }\end{array}$ & & & & & & & & & \\
\hline Resting & $\begin{array}{l}90.82 \\
(11.18)\end{array}$ & $\begin{array}{l}86.60 \\
(6.01) \\
\end{array}$ & $\begin{array}{l}-4.22 \\
(-5.17)\end{array}$ & $\begin{array}{l}120.91 \\
(5.99)\end{array}$ & $\begin{array}{l}111.91 \\
(7.19)\end{array}$ & $\begin{array}{l}-9.00 \\
(1.20)\end{array}$ & $\begin{array}{l}81.82 \\
(6.93)\end{array}$ & $\begin{array}{l}78.36 \\
(9.20) \\
\end{array}$ & $\begin{array}{l}-3.46 \\
(2.22)\end{array}$ \\
\hline Recovery & $\begin{array}{l}90.91 \\
(9.83) \\
\end{array}$ & \begin{tabular}{|l|}
85.40 \\
$(7.92)$ \\
\end{tabular} & $\begin{array}{l}-5.51 \\
(-1.91) \\
\end{array}$ & $\begin{array}{l}115.45 \\
(6.88) \\
\end{array}$ & $\begin{array}{l}114.91 \\
(6.72)\end{array}$ & $\begin{array}{l}-0.54 \\
(-0.16)\end{array}$ & $\begin{array}{l}81.27 \\
(8.32)\end{array}$ & $\begin{array}{l}85.64 \\
(7.71)\end{array}$ & $\begin{array}{l}4.37 \\
(-0.61)\end{array}$ \\
\hline $\begin{array}{l}\text { Systolic } \\
\text { BP }\end{array}$ & & & & & & & & & \\
\hline Resting & $\begin{array}{l}103.09 \\
(6.77)\end{array}$ & $\begin{array}{l}102.40 \\
(6.98)\end{array}$ & $\begin{array}{l}-0.69 \\
(0.21)\end{array}$ & $\begin{array}{l}137.45 \\
(14.03) \\
\end{array}$ & $\begin{array}{l}132.73 \\
(6.71)\end{array}$ & $\begin{array}{l}-4.72 \\
(-7.32)\end{array}$ & $\begin{array}{l}109.64 \\
(5.73)\end{array}$ & $\begin{array}{l}116.18 \\
(5.40)\end{array}$ & $\begin{array}{l}6.54 \\
(-0.17)\end{array}$ \\
\hline Recovery & $\begin{array}{l}104.91 \\
(5.89) \\
\end{array}$ & $\begin{array}{l}104.80 \\
(9.00) \\
\end{array}$ & $\begin{array}{l}-0.11 \\
(3.11) \\
\end{array}$ & $\begin{array}{l}139.09 \\
(11.84) \\
\end{array}$ & $\begin{array}{l}131.45 \\
(8.86) \\
\end{array}$ & $\begin{array}{l}-7.64 \\
(-2.99) \\
\end{array}$ & $\begin{array}{l}111.27 \\
(2.41) \\
\end{array}$ & $\begin{array}{l}112.91 \\
(3.83) \\
\end{array}$ & $\begin{array}{l}1.64 \\
(1.42) \\
\end{array}$ \\
\hline $\begin{array}{l}\text { Dystolic } \\
\text { BP }\end{array}$ & & & & & & & & & \\
\hline Resting & $\begin{array}{l}65.09 \\
(5.54) \\
\end{array}$ & $\begin{array}{l}64.60 \\
(4.90) \\
\end{array}$ & $\begin{array}{l}-0.49 \\
(-0.64) \\
\end{array}$ & $\begin{array}{l}86.55 \\
(7.90) \\
\end{array}$ & $\begin{array}{l}85.09 \\
(6.72) \\
\end{array}$ & $\begin{array}{l}-1.46 \\
(-1.19) \\
\end{array}$ & $\begin{array}{l}66.55 \\
(3.59) \\
\end{array}$ & $\begin{array}{l}68.00 \\
(3.69) \\
\end{array}$ & $\begin{array}{l}1.45 \\
(0.10) \\
\end{array}$ \\
\hline Recovery & $\begin{array}{l}66.55 \\
(4.57)\end{array}$ & $\begin{array}{l}64.20 \\
(4.94)\end{array}$ & $\begin{array}{l}-2.35 \\
(0.37)\end{array}$ & $\begin{array}{l}86.91 \\
(7.56)\end{array}$ & $\begin{array}{l}84.00 \\
(7.27)\end{array}$ & $\begin{array}{l}-2.91 \\
(-0.29)\end{array}$ & $\begin{array}{l}67.30 \\
(4.62)\end{array}$ & $\begin{array}{l}69.82 \\
(5.40)\end{array}$ & $\begin{array}{l}2.52 \\
(0.78)\end{array}$ \\
\hline
\end{tabular}

\section{Figures}


A.

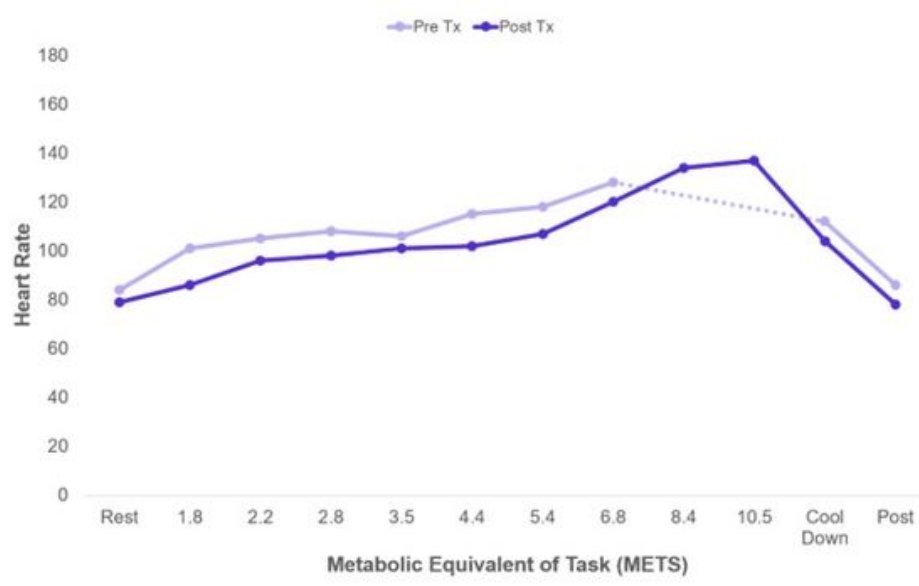

B.

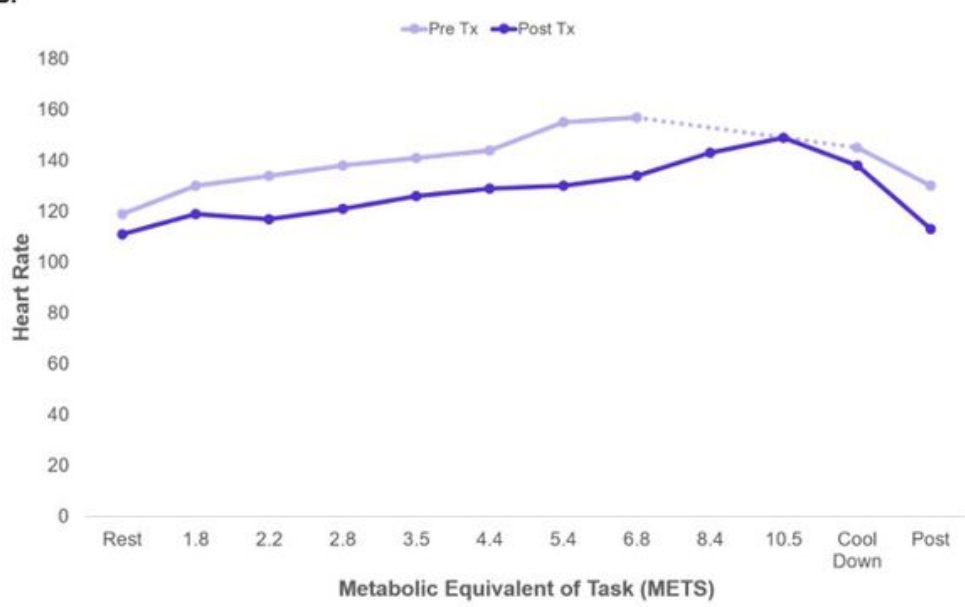

c.

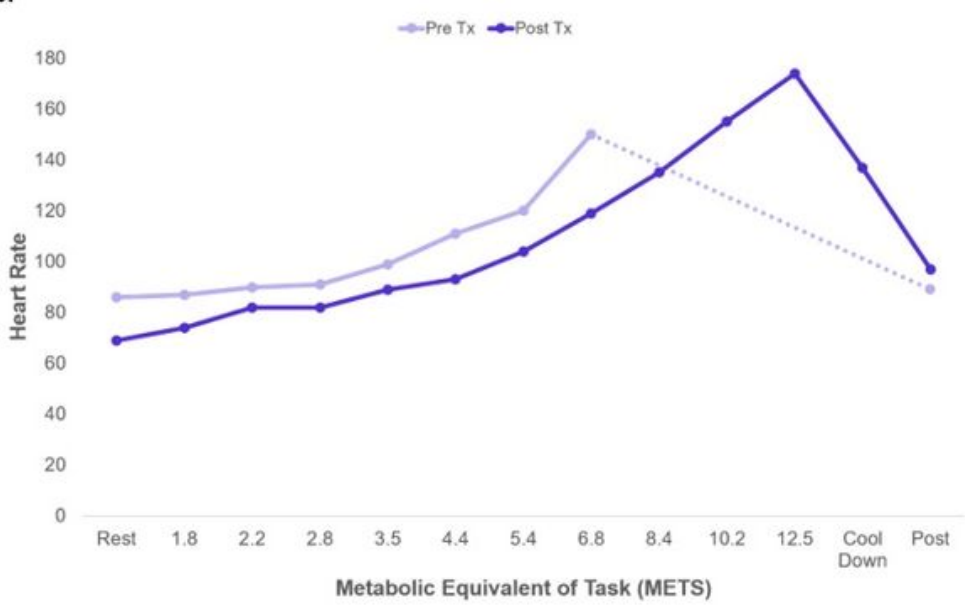

\section{Figure 1}

Heart Rate and Blood Pressure $(\mathrm{mm} \mathrm{Hg})$ at Rest, During Exercise, and Five minutes Post-Exercise During the Pre- and Post- Tolerance Test for Patients A, B, and C. 
A.

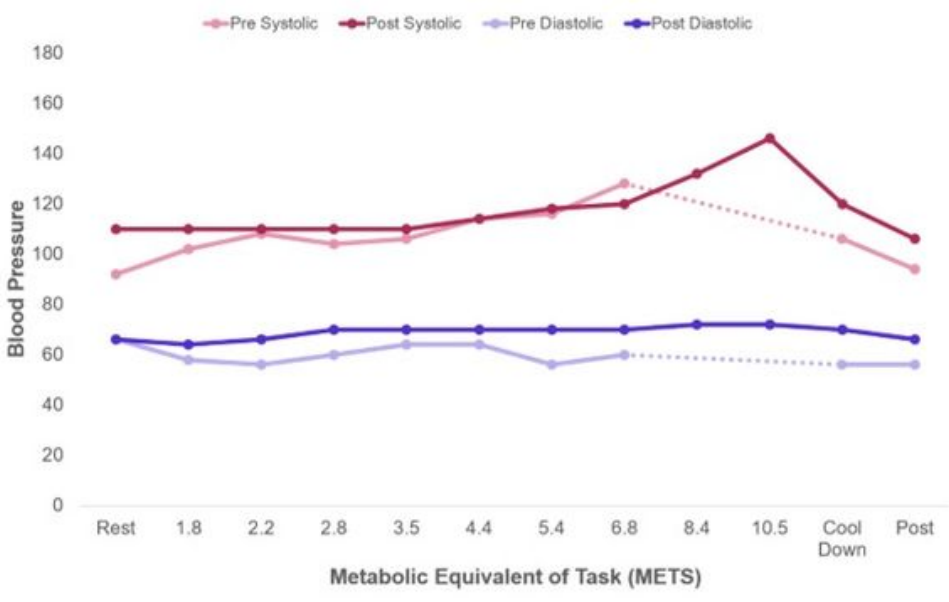

B.

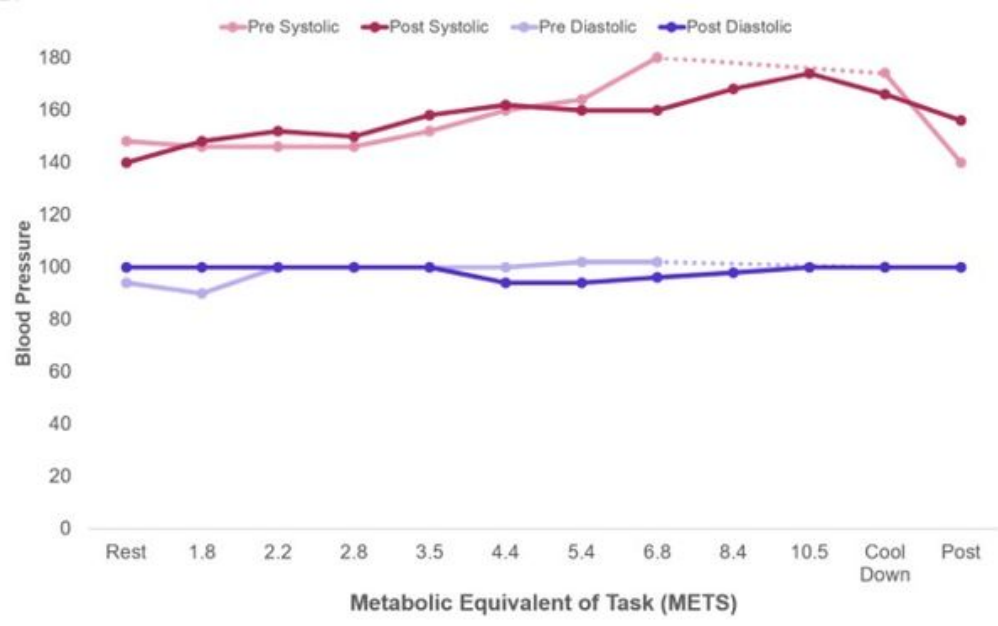

c.

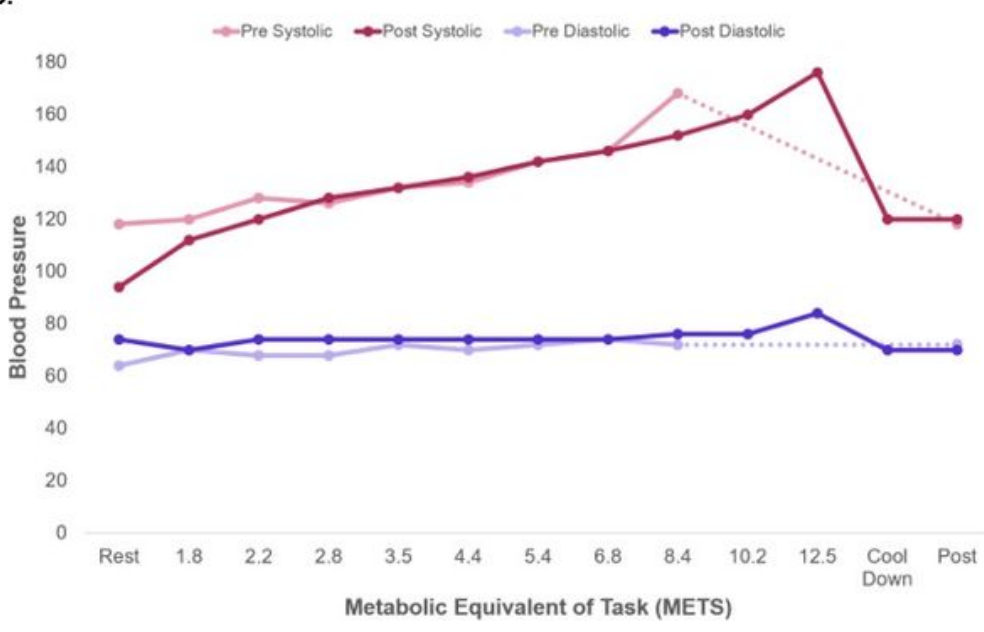

\section{Figure 2}

Blood Pressure $(\mathrm{mm} \mathrm{Hg})$ at Rest, During Exercise, and Five minutes Post-Exercise During the Pre- and Post- Tolerance Test for Patients A, B, and C.

\section{Supplementary Files}


This is a list of supplementary files associated with this preprint. Click to download.

- PCSCaseReportEBiomedicineFINALsupplementaryMaterials.docx 